УДК 336.713

\author{
Юлія Грудзевич, \\ кандидат економічних наук, старший викладач, \\ Східносвропейський національний університет імені Лесі Українки, \\ кафедра фінансів та кредиту, \\ м. Луцьк; ORCID ID 0000-0002-2790-5681 \\ email:grudzevychukr@gmail.com \\ Оксана Клебан, \\ викладач методист, \\ Вишнянський коледж Львівського НАУ, \\ c. Вишня; ORCID ID 0000-0001-8382-9807 \\ email:buxgaltervyshnja@gmail.com \\ Уляна Булик, \\ викладач, \\ Вишнянський коледж Львівського НАУ, \\ с. Вишня; ORCID ID 0000-0002-2908-010X \\ email:ubiamfree1981@gmail.com \\ Марія Рондяк, \\ викладач, \\ Вишнянський коледж Львівського НАУ, \\ с. Вишня; ORCID ID 0000-0003-0077-0542 \\ email:mariarondiak18@gmail.com
}

https://doi.org/10.29038/2411-4014-2020-03-162-167

\title{
ВИНИКНЕННЯ ТА ПЕРСПЕКТИВИ РОЗВИТКУ БЛОКЧЕЙН-ТЕХНОЛОГІЙ В УКРАЇНI
}

Розглянуто основні передумови розвитку криптовалют і блокчейн-технологій. Визначено основні цілі i завдання при використанні віртуальних активів. Досліджено основні моменти та передумови виникнення блокчейн-технологій в світі та Україні. Розглянуто основні праці вітчизняних і зарубіжних вчених, проаналізовано практичні доробки і нормативно-правову базу державного регулювання даної галузі.

Проведено аналіз позитивних і негативних боків використання криптовалюти та впровадження ії̈ в країнах iз розвиненою економікою. Досліджено проблеми та переваги у сфері застосування технології блокчейн в Україні та світі. Визначено перспективні напрями та основні тенденції розвитку криптовалюти та блокчейну.

Вивчено вплив впровадження криптовалют і блокчейн-технологій в банківську сферу.

Виділено основні переваги блокчейн-технологій, які базуються на зручності і оптимальності системи фінансових послуг, залученні нових інструментів фінансово-кредитного механізму.

Встановлені основні чинники та передумови для подальшого розвитку криптовалют і блокчейнтехнологій в Україні та світі.

Ключові слова: криптовалюта, віртуальний банк, блокчейн-технології, інтернетбанкінг, фінансові технології.

Юлия Грудзевич, кандидат економических наук, старший преподаватель, Восточноевропейський национальный университет имени Леси Украинки, кафедра финансов и кредита,

г. Луцк

Оксана Клебан, преподаватель-методист, Вишнянський коледж Львовського НАУ, 
Уляна Булик, преподаватель,

Вишнянський коледж Львовського НАУ, с. Вишня

Мария Рондяк, преподаватель, Вишнянський коледж Львовського НАУ, с. Вишня

\title{
ВОЗНИКНОВЕНИЕ И ПЕРСПЕКТИВЫ РАЗВИТИЯ БЛОКЧЕЙН- ТЕХНОЛОГИЙ В УКРАИНЕ
}

Рассмотрены главные предусловия развития криптовалют і блокчейн-технологий. Определены главные цели и задания при использовании виртуальных активов. Исследованы главные моменты и предусловия возникновения блокчейн-технологий в мире и Украине. Рассмотрены главные работы оттечественных и зарубежных учених, проанализированы практические доработки и нормативно-правовая база государственного регулирования данной отрасли.

Проведен анализ позитивных и негативных сторон использования криптовалют и их внедрения в странах с развитой економикой. Исследованы проблемы и преимущества в сфере использования технологий блокчейн в Украине и мире. Определены перспективные направления и главные тенденции развития криптовалюты и блокчейна.

Изучено влияние внедрения криптовалют и блокчейн-технологий в банковськую сферу.

Виделены главные преимущества блокчейн-технологий, которые базируются на опытности и оптимальности системы финансовых услуг, залучении новых инструментов финансово-кредитного механизма.

Установлены главные факторы и предусловия для дальнейшего развития криптовалют и блокчейнтехнологий в Украине и мире.

Ключевые слова: криптовалюта, виртуальный банк, блокчейн-технологии, интернетбанкинг, финансовые технологии.

\author{
Yuliya Grudzevych, \\ PhD in Economics, \\ Lesya Ukrainka Eastern European National University, \\ Department of Finance and Credit, \\ Lutsk \\ Oksana Kleban, \\ teacher Methodist Vyshnia College of Lviv NAU, \\ Vyshnia \\ Uliana Bulyk, \\ teacher Vyshnia College of Lviv NAU, \\ Vyshnia \\ Maria Rondiak, \\ teacher Vyshnia College of Lviv NAU, \\ Vyshnia
}

\section{THE EMERGENCE AND PROSPECTS FOR THE DEVELOPMENT OF BLOCKCHAIN TECHNOLOGIES IN UKRAINE}

Blockchain is a technology for processing, storing information and identifying of customers. Literally from English blockchain (blockchain) is translated as "Chain of blocks", and the technology itself was proposed in 2008 by Satoshi Nakamato (pseudonym of a person or group of people).

The purpose of writing the article is to study and identify regularity and prospects for the application of progressive and practical information technologies in Ukraine and the world.

The main features of blockchain technology: 
-transparency - the blockchain stores data on all conducted operations throughout the history of the system (cryptocurrency)

-stability - you can't remove or replace information "behindhand", but only to implement a new agreement

-independence - information is not stored on one central server, but on many computers of network participants.

The operation of the blockchain can be compared with Torrent - the functioning of the system takes place in P2P mode (peer to peer - computer network, where all participants are equal). When we download a movie from the tracker, the central server is not used. All transactions are directly conducted between network participants. And they are carried out due to the fact that their computers are connected to one network - a blockchain.

The widespread popularity and spread of blockchain technology is in demand to develop applications that work on the principles of this innovation, and relevant IT professionals. The market is even short of blockchain system developers in general, and especially those who have the skills to work with distributed databases.

However, the blockchain system also has its drawbacks. For example, because the data are stored on all computers of participants, for registration of operations it is required processing large amounts of data, which causes increased demands on the computer and to Internet speed for network members. This fact also causes great energy consumption for maintenance of operations in the system, for example, according to economists' calculations for next year's electricity costs bitcoin services in the world will be comparable to annual energy consumption of a small country such as Denmark.

Blockchain technology is not regulated by any legislation that causes additional legal risks, for example, if your account is hacked by hackers, so this area of technology processing and storage of information requires proper legislative and legal regulation both at the level of Ukraine and at worldwide.

Summing up, we can say that:

- Blockchain is a technology that allows you to implement the most sustainable digital registers in the world.

-The number of successful startups in this field is ten times greater than in traditional IT.

-Public blockchain databases are not controlled by any organization or state. training.

- Recording in public blockchains is available to absolutely everyone. You need only have minor technical

-Using of Blockchain very often eliminates the need in intermediaries.

- States consider and adopt legislative initiatives in this direction.

The principles underlying the technology are extremely strong, which is the key to further development.

Keywords: cryptocurrency, virtualbank, blockchain technology, internet banking, financial technologies.

\section{Постановка проблеми та її значення}

Глобалізація невпинно змінює світ і наше середовище а інтернет та інформаційні технології виступають елементами цього руху. Блокчейн - $є$ певною новою та фундаментальною технологією, яка дозволяє вивести цей процес на зовсім інший рівень. Швидкий розвиток інформаційних та цифрових технологій підвищує попит до соціальних мереж, пошукових систем та on-line магазинів, що відповідно вимагає вдосконалення та введення інновацій у фінансово кредитних механізмах.

Коли в фінансовій сфері йде постійна боротьба за клієнта, а також виникає необхідність оптимізації витрат, це породжує створення нових технологій, зокрема такого явища - як блокчейн.

Якщо в світі поняття блокчейну є досить поширеним, то в Україні це є порівняно нова категорія, яка потребує детальнішого розвитку та вивчення.

Аналіз останніх досліджень і публікацій Дослідження в галузі віртуальних активів спираються на теоретичні праці вітчизняних та зарубіжних вчених, практичні розробки i нормативно-правову базу державного регулювання в цій галузі. В українській економіці розробки теорії та практики присвячені праці таких авторів, як С.В.Волосович, В.С. Гава, О.В. Карпов, С.В. Науменкова, І.П.Ситник, Н.Г. Яцків та інші. Більшість вчених вважають, що такі технології, як «блокчейн» міцно завойовують своє місце в інформаційноцифровій системі, проте й досі існує ряд проблем, що не дозволяє впровадити їх в щоденну діяльність. Тому вважаємо за потрібне більш детально дослідити питання сутності блокчейн, його можливості, перспективи розвитку та проблеми пов'язані з ними у світі та Україні. Водночас залишається актуальним дослідження ризиків, які мають місце при використанні даної технології.

Мета і завдання статті полягає в аналізі впливу впровадження криптовалют і блокчейн-технологій в банківську сферу та дослідженні основних чинників та передумов для їх подальшого розвитку.

\section{Викладення основного матеріалу та обгрунтування отриманих результатів дослідження}

Вперше про технологію блокчейн було згадано в 2009 році коли світ дізнався про криптовалюту «біткоін» і після чого було розроблено інші криптовалюти, такі як, ефіріум (eth), ріпл і лайткоін. В основному ця технологія зпозиціонувала себе з досить позитивної сторони, а це сприяло їі дальшому поширенні в економіку і на даний момент блокчейн застосовується не тільки в банківській сфері, але і в сфері державного управління, 
юриспруденції та інших, в тому числі і для цифрового посвідчення особи. Блокчейн стартапи від Сіvіс і UniquID Wallet дозволяють людям створювати цифрові документи, які можуть засвідчувати особу, і можливо, в майбутньому вони замінять «традиційні» паспорти, водійські права та інші документи[4].

Блокчейн, або інакшими словами ланцюг або схема блоків транзакцій (англ. Blockchain, Block chain від block - блок, chain - ланцюг) — розподілена база даних, що зберігає впорядкований ланцюжок записів (так званих блоків), який постійно довшає. Така інформація є повністю захищеною від підробки та спотворення. Кожен блок містить часову позначку, хеш попереднього блоку та дані транзакцій, подані як хеш-дерево[3].

Таку розподілену базу даних закладено в основу криптовалюти Bitcoin (вона була описана 2008 i реалізована 2009 року), і яка слугує певною бухгалтерською книгою для всіх операцій. Таку базу називають Блокчейн.

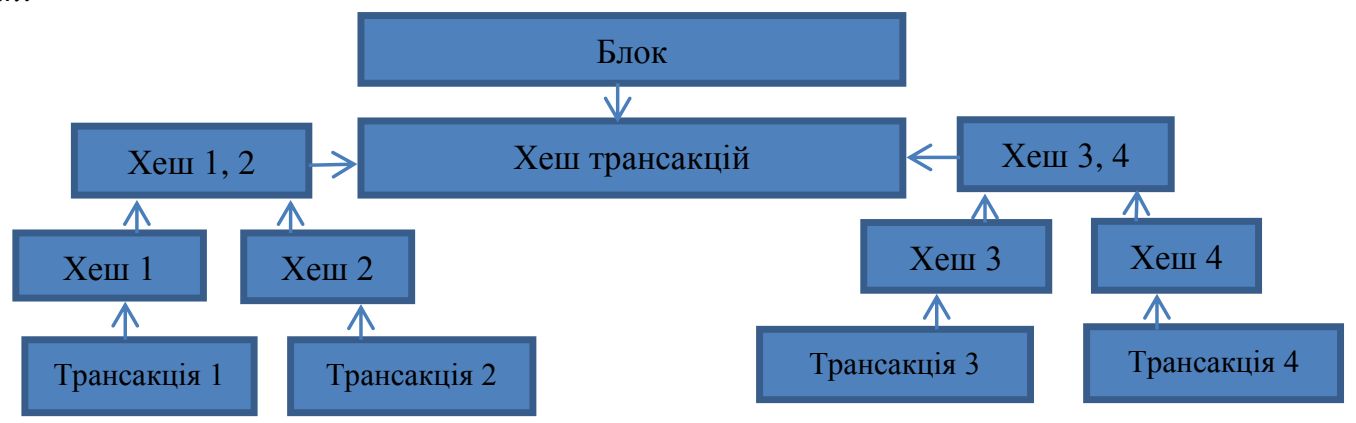

Рис. 1. Схема блоку трансакиій

Джерело: побудовано автором за даними [4].

Головні особливості блокчейн технології:

- прозорість - в блокчейні зберігається вся інформація про здійснені операції за всю історію створення системи (криптовалюти);

- стабільність - видалення чи заміну інформації не можливо здійснити, а тільки через проведення нової угоди;

- незалежність - інформація зберігається на всіх комп'ютерах учасників мережі а не на одному центральному сервері [5, с.15-22].

Такі міжнародні платіжні системи, як SWIFT, MasterCard й VISA зацікавлені в розробці планів стосовно використання блокчейну. Також відомо, що в Естонії держава використовує таку електронну блокчейнсистему для обліку громадянства.

Blockchain передусім можна вважати технологією, хоча поки що на ранній стадії розвитку. В певній мірі Blockchain це $\epsilon$ несуча технологія i за іï допомогою можна створювати будь-який сервіс. На даний час це $\epsilon$ досить перспективним, зручним і вигідним явищем, але і в цій сфері необхідне ще подальше вдосконалення, щоб ця система стала доступною в широкому використанні [11, с.157-160].

Кожен окремий Blockchain - це завжди спільнота чи певна система. Всі вони діляться на два типи: публічні та приватні — public blockchain and private blockchain. На сьогоднішній день найбільш поширеним типом є бюджена модель публічних blockchain.

Технологія блокчейн $є$ децентралізованою, що означає, що транзакції обробляються досить великою кількістю спеціальних учасників системи, які називаються майнерами. Таким учасником системи може стати будь-який бажаючий, який має відповідне обладнання та програмне забезпечення [3].

Як правило в системах блокчейн майнери виконують наступні функції:

- здійснюють зберігання копії інформації, що в свою чергу забезпечує захист системи від втрати i підробки даних;

- затверджують проведення транзакцій в системі;

- здійснюють перевірку операцій, які були проведені іншими майнерами.

Головним мотивом діяльності майнера в системі блокчейн $є$ винагорода за проведення транзакції, а також комісії, які виплачууть майнерам учасники угоди за здійснені транзакції. Така сума винагороди може досягати 0,5-1 млн. доларів США в день [5].

Також слід відзначити, що для здійснення трансакцій в блокчейн мережі важливим елементом $€$ спеціальні гаманці (wallet), які використовуються для зберігання інформації, наприклад про придбану криптовалюту. Такі гаманці можуть мати мобільну, онлайн, апаратну або десктопну форму. Онлайн блокчейн гаманець можна відкрити за 5-10 хвилин, попередньо зареєструвавшись на відповідних спеціальних фінансових порталах. Десктопні передбачають встановлення програми на ПК, а мобільні - на комунікатор. Апаратний гаманець - це флешка для зберігання даних, вони характеризуються більшою надійністю ніж інші, 
так як не мають постійного доступу до мережі Інернет, а це унеможливлює ризик злому системи хакерами. Проте для здійснення таких операцій постійно доведеться «переводити» криптовалюту 3 апаратного на інші гаманці й навпаки.

Слід відмітити, що дані про гаманці і транзакції з ними захищені наскрізним шифруванням. Підтвердження операцій 3 продажу активів між покупцем i продавцем здійснюється за допомогою використання криптографічних ключів, тобто спеціальних цифрових кодів, хоча відомі випадки, коли мало місце зламування онлайн блокчейн гаманців. В таких моментах буде значно безпечнішим зберігати дані офлайн на флешці. Транзакція в блокчейні проводиться досить щвидко, хоча обробка і підтвердження операції може зайняти до 15 хвилин.

Як правило, блокчейн гаманці припускають анонімність, тобто не можна встановити, хто здійснює операцію. Це допоможе зберегти ваші активи від сторонніх поглядів, але несе і додаткові ризики - адже якщо користувач забуде реквізити доступу до гаманця - він втрачає активи [4].

Проте, система блокчейн також має свої недоліки.

Одним з недоліків можна вважати такий фактор, який вимагає якісного зв’язку та швидкості інтернету а також підвищених вимог до комп'ютера, тому що дані зберігаються на всіх комп'ютерах учасників і реєстрація операцій потребує обробки великих обсягів даних. Крім цього, для обслуговування операцій в системі йдуть досить великі енерговитрати [5].

Технологія блокчейн не регулюється жодним законодавством, що несе додаткові юридичні ризики, наприклад, якщо ваш рахунок буде зламаний хакерами, тому ця сфера технологій обробки і зберігання інформації потребує належного законодавчо-правового регулювання як на рівні України, так i на загальносвітовому рівні.

Висновки і перспективи подальших досліджень

Як підсумок, можна зазначити, що:

- Blockchain як технологія вже відбулась, процес змін вже почався, і він незупинний.

- Блокчейн - це технологія, яка дозволяє реалізовувати найстійкіші цифрові реєстри в світі практично безкоштовно, в той час як корпорації та держави витрачають мільярди доларів для забезпечення цілісності своїх даних.

- На даний момент відбувається стрімка адаптація технології до традиційних секторів економіки.

- Кількість успішних стартапів у цій сфері в десятки разів більша, ніж в традиційному IT.

- Жодна з організацій чи держав не може контролювати бази даних публічних блокчейн.

- При наявній технічній підготовці, навіть незначній, запис в публічні блокчейни доступний абсолютно кожному.

- Застосування Blockchain забезпечує здійснення операцій без посередників.

- Держави зацікавлені в розгляді та ухваленні законодавчих ініціатив щодо технології блокчейн.

В подальшому необхідно врегулювати нормативно-правове забезпечення даної системи інформаційного простору, щоб уникнути будь яких юридичних ризиків та забезпечити сталий і прогресивний розвиток досліджуваної сфери технологій обробки і зберігання інформації як на рівні України, так і на загальносвітовому рівні.

\section{Джерела та література}

1. Cryptocurrency Market Capitalizations. URL: https://coinmarketcap.com

2. Royal Bank of Canada Website.URL: https://www.rbcroyalbank.com/personal.html

3. This top bitcoin booster thinks the cryptocurrency will hit $\$ 40,000$ a coin this year - but believes $90 \%$ of other ones will fail [Електронний ресурс] / Режим доступу: http://www.businessinsider.com/bitcoin-foundation-head-llewclaasen-90-of-cryptocurrencies-to-fail-2018-2?IR=T

4. Блокчейн в Украине: Что это за технология и чем она полезна [Электронный ресурс] / Режим доступа: https://112.ua/statji/blokcheyn-v-ukraine-chto-eto-za-tehnologiya-i-chem-ona-polezna-417161.html

5. Волосович С.В. Домінанти технологічних інновацій у фінансовій сфері / С.В. Волосович // Економічний вісник університету. 2017. Вип. 33(1). С. 15-22.

6. Гава В.С. Криптовалюта нового поколения bitbon / В.С. Гава // Економіка: теорія та практика. 2016. № 2. C. $8-10$.

7. Інформаційне агентство ЛІГАБізнесІнформ. URL: http://finance.liga.net

8. Карпов О.В. Аналіз і порівняння історичної волатильності золота та криптовалюти Bitcoin / Ю.В. Карпов // Науковий вісник Національної академії статистики, обліку та аудиту. 2014. № 4. С. 13-18.

9. Науменкова С.В. Цифрові валюти у контексті суспільної довіри до грошей / С.В. Науменкова, В.І. Міщенко, С.В. Міщенко // Фінансово-кредитна діяльність: проблеми теорії та практики. 2018. № 2(25) 
10. НБУ визначив статус Bitcoin в Україні. URL: https://biz.nv.ua/ukr/finance/nbu-viznachiv-status-bitcoin-vukrajini-1910824.html

11. Ситник І.П. Аналіз сучасного стану та перспектив розвитку криптовалюти BITCOIN в умовах розвитку інформаційної економіки / І.П. Ситник, Б.І. Пюро // Вісник Одеського національного університету. Серія «Економіка». 2017. Том 22. Вип. 1. С. 157-160.

\section{References}

1. Cryptocurrency Market Capitalizations. URL: https://coinmarketcap.com

2. Royal Bank of Canada Website.URL: https://www.rbcroyalbank.com/personal.html

3. This top bitcoin booster thinks the cryptocurrency will hit $\$ 40,000$ a coin this year - but believes $90 \%$ of other ones will fail [Електронний ресурс] / Режим доступу: http://www.businessinsider.com/bitcoin-foundation-head-llewclaasen-90-of-cryptocurrencies-to-fail-2018-2?IR=T

4. Blokchein v Ukraini: Chto eto za tehnologyia y chem ona polezna [elektronniy resurs] / regym dostupa: https://112.ua/statji/blokcheyn-v-ukraine-chto-eto-za-tehnologiya-i-chem-ona-polezna-417161.html

5. Volosovych S.V. Dominanty tehnologichnyh innovatsiy v finansoviy sferi / S.V. Volosovich // Ekonomichnyi visnyk universytetu. 2017. Vyp. 33(1). S. 15-22.

6. Gava V.S. Kryptovaluta novogo pocoleniya bitbon / V.S. Gava // Ekonomika: teoriya ta praktyka. 2016. № 2. S. $8-10$.

7. Informatsiyne agenstvo LIGA Biznes Inform. URL: http://finance.liga.net

8. Karpov O.V. Analiz i porivnianna istorychnoi volatyvnosti zolota ta kryptovaluty Bitcoin / U.V. Karpov // Naukovyi visnyk Natsionalnoi akademii statystyky, obliku ta audytu. 2014. № 4. S. 13-18.

9. Naumenkova S.V. Tsyfrovi valuty u kontesti suspilnoi doviry do hroshei / S.V. Naumenkova, V.I. Mishchenko, S.V. Mishchenko // Finansovo-kredytna diyalnist: problemy teorii ta praktyka. 2018. № 2(25)

10. NBU vyznachyv status Bitcoin v Ukraini. URL: https://biz.nv.ua/ukr/finance/nbu-viznachiv-status-bitcoin-vukrajini-1910824.html

11. Sytnyk I.P. Analiz suchasnogo stanu ta perspektyv rozvytku kryptovaluty BITCOIN v umovah rozvytku informatsiynoi nauky / I.P. Sytnyk, B.I. Pyuro // Visnyk Odeskogo natsionalnogo universytetu. Seriya Ekonomika. 2017. Tom 22. Vyp. 1. S. 157-160.

Стаття надійшла до редакції 20.08.2020 р. 